\title{
Recenze
}

\section{Benda, M. (2019). Všímavost a soucit se sebou: Proměna emocí v psychoterapii. Praha: Portál. 230 s. ISBN 978-80-262-1524-0.}

Autor knihy Všimavost a soucit se sebou se dlouhodobě zabývá tématy všímavosti, meditace a soucitu se sebou bohatou publikační činností i dlouhodobou praxí. Je proto radostí vidět, že se rozhodl dát svým nabitým znalostem a zkušenostem ucelený teoretický podklad v podobě této knihy a přehledně je uvést $\mathrm{v}$ kontext současné psychoterapeutické praxe. V knize uceleně a systematicky včleňuje všímavost a soucit se sebou do kontextu psychologie i psychoterapeutické praxe, jíž tento koncept nabízí jako nástroj vhodný pro všechny psychoterapeutické směry. Koncepcí studu a soucitu se sebou tak autor přináší další možný pohled na rozmanitou psychopatologii a její etiologii. Tyto podnětné informace může zejména odborný čtenář $-\mathrm{v}$ dobrém slova smyslu - kriticky konfrontovat s více tradičními poznatky. Autor své pojetí nabízí srozumitelně pro čtenáře z laické veřejnosti, odborníky z psychoterapeutické i akademické obce.

Kniha se skládá ze čtyř částí. V první části s názvem Tři úrovně všímavosti nás autor seznamuje s konceptem všímavosti, jeho schopnostmi a vlastnostmi, ale také důležitostí býti všímavým pro terapeuta samotného. Ve druhé části nazvané Postoj k proživanému a narativnímu Já se dále zabývá psychologickými koncepty, které mají pro předkládané téma specifický význam a dokreslují úvahy o funkcích všímavosti v psychoterapeutickém procesu. Třetí část, Psychoterapeutická změna, se soustředí na specifické efekty všímavosti a soucitu se sebou v klasické psychoterapii. Čtvrtá část svůj obsah předurčuje vlastním názvem Psychoterapeutické techniky, a představuje focusing (tělesně zakotvené proživání), techniku krocení démonů v nás a techniku ideálních rodičů na praktických prríkladech několika kazuistik. Celou knihou nás provází také inspirativní cvičení na každý, aktuálně představovaný aspekt všímavosti a soucitu se sebou.

V úvodu si autor klade za úkol prozkoumat množství zajímavých a rozsáhlých témat, což ve čtenáři hned ze začátku může vzhledem $\mathrm{k}$ počtu stran vzbudit nedůvěru, jestli takovému slibu bude možno dostát. Nicméně nutno přiznat, že jsou jednotlivá témata zpracována a zařazena velmi pečlivě, i přes to, že jsou občas povrchnější, než bychom si přáli. Místy může čtenář politovat, že zajímavá poznámka není více rozvedena a zasazena do kontextu všímavosti a soucitu se sebou v knize samotné (ví však, kde bližší informace dohledat). To platí např́íklad i pro všímavou meditaci, kde autor sám uvádí, že jí v knize nebyl věnován dostatek pozornosti. I zde platí výše uvedené, tj. že existuje mnoho jiných zdrojů, kde se čtenář může tyto informace dozvědět - zatímco tato publikace sleduje svůj originální cíl, a to velmi zdařile. Autor v knize prezentuje význam všímavosti a soucitu se sebou, a přestože si je vědom přesahujících oblastí a širšího kontextu, nenechává se těmito odbočkami v knize př́liš rozptylovat. Vytvořil tak spirálu, která tok textu směřje k jednomu bodu, což je struktura známá ze zahraničních populárně-naučných publikací. Ocenění si zaslouží také vlastní přínos ve formě vlastního výzkumu, který autor na toto téma provedl. 
Autorsky je text velmi dobře zvládnutý, nelze mu upř́it odbornost, zároveň je i čtivý. Kromě řádné citace je prosycen množstvím odkazů na další literaturu ke studiu, které vzbuzují zájem a přinášejí inspiraci. Přes drobné připomínky lze knihu považovat za velmi zdařilý počin. Citované poznatky jsou aktuální a kniha není opakováním už řečeného. Ocenění si zaslouží také celkové představení teoretického rámce pro téma soucitu se sebou, který otevírá možnosti jeho dalšího zkoumání, ověřování a praktického využití nejen v psychoterapii, ale i v každodenním životě nás čtenářů.

Marek Malůš 